\title{
PENGARUH KUALITAS PELAYANAN ANGKUTAN KOTA TERHADAP KEPUASAN DAN LOYALITAS PENUMPANG DI KOTA KUPANG
}

\author{
Oktovianus Edvict Semiun \\ Dosen / Program Studi Teknik Sipil / Fakultas Teknik / \\ Universitas Katholik Widya Mandira \\ Korespondensi: oktovianusedvict@gmail.com
}

\begin{abstract}
This study is aimed to evaluate the quality of urban transportation service and its impact on passenger satisfaction and loyalty in Kupang city, NTT. Data collection was done by distributing questionnaires to 130 passengers chosen by applying random sampling technique. The survey results were analyzed by IPA method and CSI. Whereas, the relationship between importance, performance and passenger loyalty were analyzed using PLS. The results showed that the public transportation service has not reached satisfactory category with the value of CSI at 57,21\% (very poor). The results of the analysis of PLS model revealed that both importance and performance positively affected on passenger loyalty, whereas importance negatively affected the performance.
\end{abstract}

Keywords : CSI, IPA, Passenger Satisfaction and Loyalty, PLS, Public Transportation

\section{PENDAHULUAN}

Kota Kupang adalah ibukota Provinsi Nusa Tenggara Timur. Sebagai ibu kota provinsi, pemerintah Kota Kupang tentunya harus lebih memperhatikan kebutuhan masyarakat akan moda transportasi publik, salah satunya yaitu angkutan kota. Angkutan kota di Kupang berjenis mikrolet. Namun masyarakat Kota Kupang biasa menyebutnya "oto bemo" [10]. Angkutan kota tersebut sangat unik dilengkapi dengan aneka stiker, bunyi klakson yang khas serta beragam aksesoris lainnya. Bukan cuma stiker, lagu pun nonstop diputar. Ini dilakukan demi menarik calon penumpang. Dentuman musik yang kuat dari koleksi lagu-lagu terkini dengan dukungan dua sampai tiga amplifier, menjadikan angkutan kota di Kota Kupang seringkali disebut diskotik berjalan.

Kondisi kualitas angkutan kota di Kupang saat ini belum sesuai dengan standar pelayanan yang diinginkan sehingga memberikan ruang justifikasi untuk pengambilalihan layanan transportasi oleh pemerintah. Perbaikan kualitas angkutan umum di kota Kupang perlu diimbangi dengan pengendalian penggunaan kendaraan pribadi. Dengan demikian, dampaknya terhadap pengurangan kemacetan dapat maksimal.

Perilaku pengguna jasa sangat menentukan dalam proses pengambilan keputusan, termasuk perilaku pengguna jasa transportasi. Faktor psikologis pengguna jasa merupakan faktor penting yang harus dipertimbangkan dalam proses pengambilan keputusan. Faktor-faktor tersebut menurut Zeithaml, et. al [1] meliputi kualitas pelayanan (service quality), nilai kualitas yang dirasakan (perceived value) dan kepuasan pelayanan (customer satisfaction).

Penelitian mengenai kepuasan dan loyalitas penumpang sudah dilakukan sejak pertengahan 1960-an [13]. Menurut Jen et. al [2] kepuasan merupakan jembatan yang menghubungkan kualitas pelayanan dan loyalitas. Pernyataan tersebut didukung oleh [12] yakni kepuasan pelanggan merupakan salah satu faktor utama berkaitan dengan loyalitas pelanggan dan hubungan yang kontinu diantara keduanya. Sedangkan loyalitas 
pelanggan menurut Oliver [6] adalah suatu komitmen yang mendalam dari pelanggan untuk membayar kembali produk atau layanan secara konsisten di masa mendatang dan dapat menahan pengaruh dari pelayanan yang lainnya serta sangat sulit untuk mengganti produk atau layanan tersebut. Terdapat banyak penelitian mengenai hubungan antara kualitas pelayanan transportasi publik dengan kepuasan dan loyalitas penumpang diantaranya: penelitian yang dilakukan oleh [9], [7]. Oleh karena itu, dilakukan penelitian serupa dengan lokasi yang berbeda yakni di Kota Kupang.

Tujuan yang hendak dicapai dalam penelitian ini adalah untuk: (1) Mengetahui pengaruh kualitas pelayanan angkutan kota terhadap kepuasan dan loyalitas penumpang. (2) Mengetahui upaya peningkatan kualitas pelayanan angkutan kota untuk meningkatkan kepuasan dan loyalitas penumpang.

\section{METODOLOGI PENELITIAN}

Penelitian ini menjelaskan pengaruh dimensi dan komponen-komponen dari kualitas layanan angkutan kota terhadap kepuasan penumpang dan pengaruhnya terhadap loyalitas penumpang di kota Kupang. Untuk melihat hubungan antarindikator dalam penelitian ini digunakan pendekatan PLS sedangkan pengukuran kinerja pelayanan angkutan kota menggunakan metode IPA yang digambarkan dengan diagram kartesius.

Objek penelitiannya adalah angkutan kota yang dibagi dalam dua kategori yaitu berdasarkan panjang rute dan jumlah armada yang tertuang dalam Peraturan Walikota Kupang Nomor 2 Tahun 2009.

Tabel 1. Objek penelitian

\begin{tabular}{llc}
\hline \multicolumn{2}{c}{ Kategori } & Trayek \\
\hline Panjang & Rute & 05 (Terminal \\
Rute & Terpanjang & Kupang-Terminal Bello \\
& $(27,14 \mathrm{~km})$ & PP) \\
& Rute & $11 /$ C6 (Terminal \\
& terpendek & Kupang-Perumnas PP) \\
& $(5,60 \mathrm{~km})$ & $02($ Terminal \\
Jumlah & terbanyak & Kupang-Terminal Bello \\
Armada & $(117$ armada) & PP) \\
& & Paling sedikit \\
& (7 armada) & Terminal Tabun PP) \\
\hline
\end{tabular}

Pengumpulan data sekunder diperoleh dari instansi-instansi yang berkaitan dengan penelitian, yakni: (1) Data jumlah kendaraan dan rute angkutan umum jenis angkutan kota yang beroperasi dari Dinas Perhubungan Kota Kupang (2) Jumlah penduduk, (3) Peta, luas wilayah dan karakteristik trayek, (4) Studi literatur yang berkaitan dengan kinerja pelayanan angkutan umum. Sedangkan pengumpulan data primer dilakukan dengan dua teknik antara lain : teknik dokumentasi dan survey kuisioner.

\subsection{Variabel dan Indikator Penelitian}

Derajat kualitas pelayanan yang dirasakan oleh pelanggan adalah tingkat penilaian terhadap pelayanan yang dialami oleh pelanggan sehingga konsep pengembangan kinerja pelayanan angkutan kota dalam penelitian ini diperoleh dari penilaian persepsi penumpang terhadap 42 item pengukuran yang merupakan interpretasi dari 7 variabel kualitas pelayanan dan kepuasan penumpang, yakni: aksesibilitas, kehandalan, kenyamanan, keamanan dan keselamatan, pentarifan, sarana angkutan umum serta prasarana angkutan umum. Sedangkan loyalitas penumpang diperoleh dari penilaian persepsi penumpang terhadap 9 item pengukuran yang merupakan interpretasi dari 3 indikator loyalitas. Adapun indikator yang dimaksud yakni berdasarkan pendapat Gremler dan Brown [5]: Behaviour/Perilaku, Attitude/Sikap dan Cognitive/Teori atau Pandangan.

\subsection{Populasi dan Sampel}

Penyebaran kuesioner dilakukan secara acak untuk mengetahui penilaian penumpang terhadap tingkat kepentingan/harapan (importance), tingkat kepuasan/kinerja (performance) dan loyalitasnya yang diberikan oleh angkutan kota. Kuisioner disebarkan kepada responden sebanyak 130 orang berdasarkan perhitungan ukuran populasi dan sampel dengan rumus Slovin pada taraf signifikan $10 \%$ seperti pada rumus berikut:

$$
n=\frac{N}{1+N e^{2}}
$$

$$
\begin{aligned}
& \text { Keterangan : } \\
& \mathrm{n}=\text { ukuran sampel, } \\
& \mathrm{N}=\text { ukuran populasi } \\
& \mathrm{e}=\text { presisi yang digunakan (diambil } 10 \% \text { ) }
\end{aligned}
$$




\subsection{Metode IPA}

Important performance analysis (IPA) terdiri dari empat kuadran [8], [9] yakni Kuadran A (I): prioritas utama perbaikan (Concentrate here/concentration here); Kuadran B (II): pertahankan prestasi (keep up with the good work/keep achievement); Kuadran C (III): prioritas rendah (low priority) dan kuadran D (IV): berlebihan (Possibly overkill/too much). Dalam penelitian ini importance merupakan tingkat kepentingan/ harapan penumpang terhadap nilai kualitas pelayanan angkutan kota dan Performance merupakan nilai kepuasan penumpang terhadap kinerja angkutan kota.

\subsection{Customer Satisfaction Index (CSI)}

CSI digunakan untuk mengetahui tingkat kepuasan pelanggan suatu perusahaan/penyedia jasa secara menyeluruh dengan pendekatan yang mempertimbangkan penilaian pengguna terhadap kinerja penyedia jasa pada atribut-atribut yang diukur. Interpretasi nilai CSI [11] dapat dilihat pada tabel berikut:

Tabel 2. Customer Satisfaction Index Interpretation

\begin{tabular}{cc}
\hline Angka Indeks & Interpretasi \\
\hline $\mathrm{x} \leq 64 \%$ & Very poor \\
\hline $64 \%<\mathrm{x} \leq 71 \%$ & Poor \\
\hline $71 \%<\mathrm{x} \leq 77 \%$ & Cause for concern \\
\hline $77 \%<\mathrm{x} \leq 80 \%$ & Border line \\
\hline $80 \%<\mathrm{x} \leq 84 \%$ & Good \\
\hline $84 \%<\mathrm{x} \leq 87 \%$ & Very good \\
\hline $87 \% \leq \mathrm{x}$ & Excelent \\
\hline
\end{tabular}

\subsection{Loyalitas Penumpang}

Dalam penelitian ini, kategori penilaian yang digunakan untuk mendeskripsikan loyalitas penumpang angkutan kota adalah 4,01-5,00 (sangat loyal), 3,01-4,00 (loyal), 2,01-3,00 (ragu-ragu), 1,01-2,00 (kurang loyal) dan 0,00-1,00 (tidak loyal).

\section{Square}

Model persamaan struktural dalam penelitian ini merupakan model peramalan pengaruh hubungan antara tingkat harapan (importance), tingkat kinerja/kepuasan penumpang (performance) dan loyalitas penumpang angkutan kota yakni dengan menggunakan Partial Least Square (PLS). PLS sangatlah penting terutama ketika berkaitan dengan variabel dalam jumlah besar yang menyatakan informasi umum [14].

Lebih lanjut dijelaskan bahwa PLS mengurangi dampak variasi variabel bebas (X) yang tidak relevan dalam model kalibrasi dengan menyeimbangkan informasi dalam ruang variabel bebas $(\mathrm{X})$ dan variabel terikat (Y).

Langkah-langkah yang dilakukan dalam PLS meliputi merancang model struktural (Inner Model) yang menghubungkan antarvariabel laten, merancang model pengukuran (Outer Model) yang menghubungkan indikator dengan variabel latennya, mengkonstruksi diagram jalur, estimasi koefisien jalur, Loading dan Weight (Analysis Convergent Validity, Analysis Discriminant Validity, Analysis of Composite Reliability), pengujian Outer Model, evaluasi Goodness of Fit (pengujian model) dan pengujian hipotesis.

Adapun hipotesis yang diajukan dalam penelitian ini adalah :

$\mathrm{H}_{1}$ : terdapat pengaruh yang signifikan antara Importance dengan Loyalitas penumpang angkutan kota

$\mathrm{H}_{2}$ : terdapat pengaruh yang signifikan antara Importance dengan Performance penumpang angkutan kota

$\mathrm{H}_{3}$ : terdapat pengaruh yang signifikan antara Performance dengan Loyalitas penumpang angkutan kota.

\section{HASIL DAN PEMBAHASAN}

3.1 Analisis Kuadran dengan Metode IPA

Hasil pengukuran tingkat performance dan tingkat importance ditampilkan dalam tabel berikut :

\subsection{Hubungan Matematis Partial Least}


Tabel 3. Tingkat performance dan tingkat importance

\begin{tabular}{|c|c|c|c|c|c|c|}
\hline & Item Pengukuran & $\begin{array}{c}\text { Bobot } \\
\text { Kinerja } \\
(\text { Performance })\end{array}$ & $\begin{array}{c}\text { Bobot } \\
\text { Harapan } \\
(\text { Importance })\end{array}$ & $\begin{array}{c}\text { Tingkat } \\
\text { Kesesuaian } \\
(\%)\end{array}$ & $\begin{array}{l}\text { Rata-rata } \\
\text { Kinerja }\end{array}$ & $\begin{array}{l}\text { Rata-rata } \\
\text { Harapan }\end{array}$ \\
\hline \multicolumn{7}{|c|}{ Aksesibilitas } \\
\hline 1 & Waktu Pelayanan & 414 & 480 & 86.25 & 3.185 & 3.692 \\
\hline 2 & Waktu Tunggu & 387 & 520 & 74.42 & 2.977 & 4.000 \\
\hline 3 & Rute Perjalanan & 381 & 448 & 85.04 & 2.931 & 3.446 \\
\hline 4 & Perpindahan Angkutan kota & 331 & 498 & 66.47 & 2.546 & 3.831 \\
\hline 5 & Waktu Berhenti di Terminal & 408 & 459 & 88.89 & 3.138 & 3.531 \\
\hline 6 & Panjang trayek yang dilalui & 323 & 466 & 69.31 & 2.485 & 3.585 \\
\hline 7 & $\begin{array}{l}\text { Jarak Berjalan Kaki ke Tempat } \\
\text { Pemberhentian }\end{array}$ & 389 & 433 & 89.84 & 2.992 & 3.331 \\
\hline \multicolumn{7}{|c|}{ Kehandalan } \\
\hline 8 & Jumlah Tempat Duduk yang Disediakan & 389 & 437 & 89.02 & 2.992 & 3.362 \\
\hline 9 & $\begin{array}{l}\text { Ketepatan Waktu dalam mengantarkan } \\
\text { penumpang ke tujuan }\end{array}$ & 395 & 452 & 87.39 & 3.038 & 3.477 \\
\hline 10 & Kecepatan Rata-rata & 341 & 488 & 69.88 & 2.623 & 3.754 \\
\hline 11 & Waktu Tempuh & 394 & 455 & 86.59 & 3.031 & 3.500 \\
\hline 12 & $\begin{array}{l}\text { Waktu Antara Angkutan Kota yang Satu } \\
\text { dengan yang Lain (Headway) }\end{array}$ & 379 & 428 & 88.55 & 2.915 & 3.292 \\
\hline 13 & $\begin{array}{l}\text { Faktor Lingkungan akibat polusi yang } \\
\text { ditimbulkan (asap kendaraan dan } \\
\text { kebisingan) }\end{array}$ & 345 & 477 & 72.33 & 2.654 & 3.669 \\
\hline \multicolumn{7}{|c|}{ Kenyamanan } \\
\hline 14 & Mudah Turun Naik Kendaraan & 371 & 420 & 88.33 & 2.854 & 3.231 \\
\hline 15 & Tersedia Tempat Duduk Setiap Saat & 380 & 423 & 89.83 & 2.923 & 3.254 \\
\hline 16 & Kepadatan Penumpang & 401 & 451 & 88.91 & 3.085 & 3.469 \\
\hline 17 & Kualitas Tempat Duduk & 394 & 441 & 89.34 & 3.031 & 3.392 \\
\hline 18 & Suhu di dalam Angkutan Kota & 375 & 421 & 89.07 & 2.885 & 3.238 \\
\hline 19 & Keramahan Sopir dan Kondektur & 346 & 454 & 76.21 & 2.662 & 3.492 \\
\hline 20 & $\begin{array}{l}\text { Kebersihan Tempat Duduk yang } \\
\text { Disediakan }\end{array}$ & 413 & 465 & 88.82 & 3.177 & 3.577 \\
\hline 21 & Kebersihan Lantai dan Jendela & 403 & 457 & 88.18 & 3.100 & 3.515 \\
\hline 22 & $\begin{array}{l}\text { Fasilitas Pelayanan berupa TV dan } \\
\text { audio musik yang dipasang }\end{array}$ & 350 & 392 & 89.29 & 2.692 & 3.015 \\
\hline \multicolumn{7}{|c|}{ Keamanan dan Keselamatan } \\
\hline 23 & $\begin{array}{l}\text { Keamanan dan Keselamatan penumpang } \\
\text { saat naik, berada di dalam dan turun dari } \\
\text { Angkutan Kota }\end{array}$ & 359 & 503 & 71.37 & 2.762 & 3.869 \\
\hline \multicolumn{7}{|c|}{ Pentarifan } \\
\hline 24 & Besar Tarif yang Berlaku & 330 & 471 & 70.06 & 2.538 & 3.623 \\
\hline 25 & $\begin{array}{l}\text { Distribusi Informasi akan Tarif dalam } \\
\text { Angkutan Kota }\end{array}$ & 339 & 421 & 80.52 & 2.608 & 3.238 \\
\hline 26 & Sistem Pembayaran Tarif & 384 & 430 & 89.30 & 2.954 & 3.308 \\
\hline \multicolumn{7}{|c|}{ Sarana Angkutan Umum } \\
\hline 27 & Jenis Kendaraan & 387 & 439 & 88.15 & 2.977 & 3.377 \\
\hline 28 & Dimensi dan Desain Kendaraan & 397 & 446 & 89.01 & 3.054 & 3.431 \\
\hline 29 & Umur Kendaraan & 360 & 497 & 72.43 & 2.769 & 3.823 \\
\hline 30 & Jumlah Armada yang Beroperasi & 373 & 421 & 88.60 & 2.869 & 3.238 \\
\hline \multicolumn{7}{|c|}{ Prasarana Angkutan Umum } \\
\hline 31 & Ketersediaan Halte & 327 & 463 & 70.63 & 2.515 & 3.562 \\
\hline 32 & Kriteria Bangunan Halte & 371 & 444 & 83.56 & 2.854 & 3.415 \\
\hline 33 & Ukuran Halte & 384 & 442 & 86.88 & 2.954 & 3.400 \\
\hline 34 & Tata Letak Halte & 375 & 426 & 88.03 & 2.835 & 3.277 \\
\hline 35 & Jarak antar Halte & 322 & 481 & 66.94 & 2.477 & 3.700 \\
\hline 36 & Lokasi Halte & 333 & 465 & 71.61 & 2.562 & 3.577 \\
\hline 37 & Ketersediaan Terminal & 405 & 459 & 88.24 & 3.115 & 3.531 \\
\hline 38 & Kriteria Bangunan Terminal & 383 & 424 & 90.33 & 2.946 & 3.262 \\
\hline 39 & Ukuran Terminal & 381 & 431 & 88.40 & 2.931 & 3.315 \\
\hline 40 & Tata Letak Terminal & 392 & 477 & 82.18 & 3.015 & 3.669 \\
\hline 41 & Lokasi Terminal & 384 & 437 & 87.87 & 2.954 & 3.362 \\
\hline 42 & $\begin{array}{l}\text { Tempat Parkir Kendaraan Angkutan } \\
\text { Kota }\end{array}$ & 335 & 433 & 77.37 & 2.577 & 3.331 \\
\hline
\end{tabular}




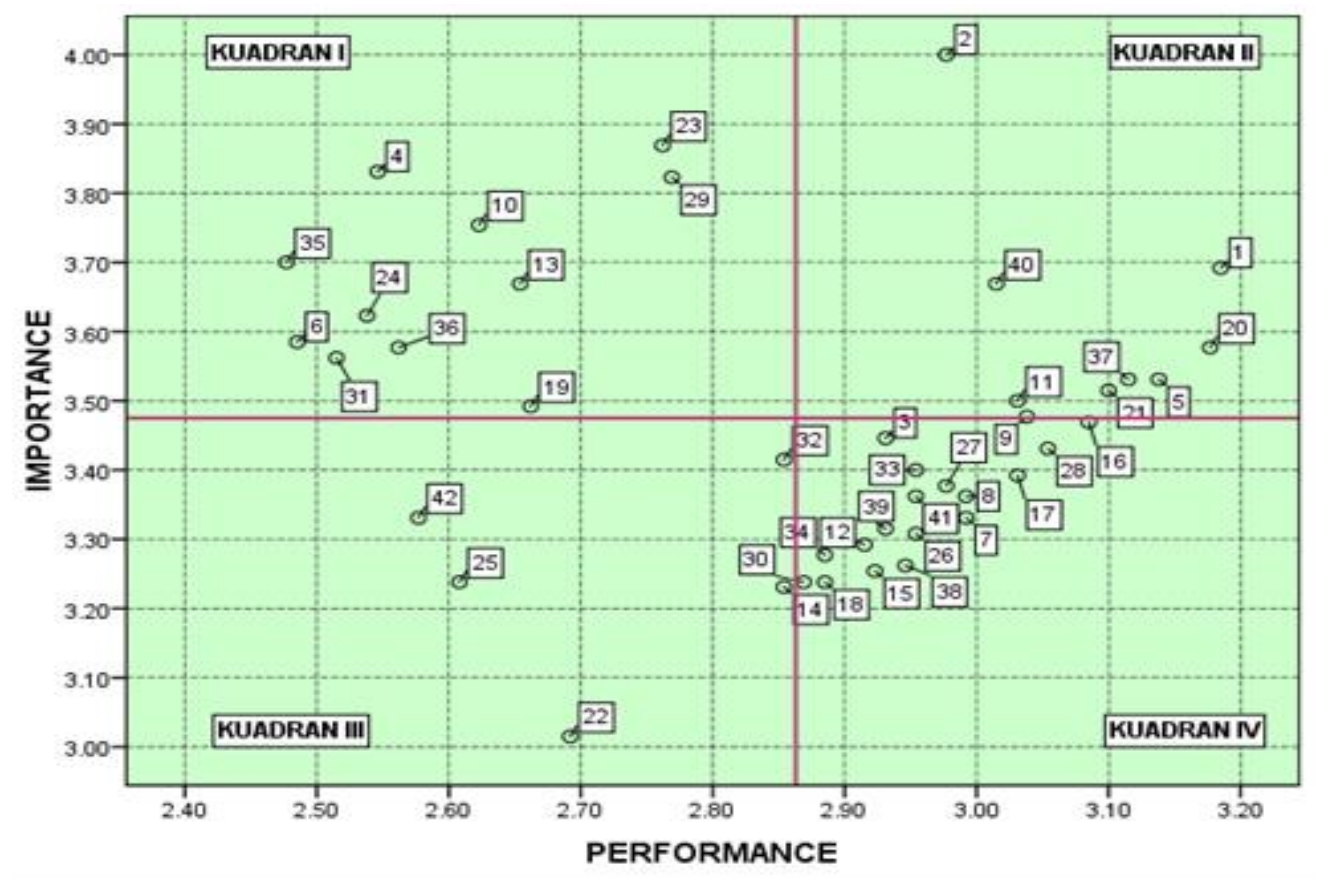

Gambar 1. Diagram importance performance

Tahap selanjutnya adalah melakukan pemetaan antara tingkat harapan (importance) dan tingkat kinerja (performance) dalam diagram kartesius Importance-Performance Analysis. Hasil pengukuran tingkat performance dan tingkat importance kemudian diplot dalam diagram importance performance.

Pada Gambar 1 dapat dilihat bahwa 42 atribut terbagi ke dalam empat kuadran.

1. Kuadran I menunjukkan bahwa atribut yang berada pada kuadran ini masih belum sesuai dengan yang diharapkan oleh penumpang, sehingga operator harus bisa lebih memperhatikan dan meningkatkan lagi faktor-faktor tersebut. Atribut yang dimaksud antara lain: perpindahan, panjang trayek yang dilalui, kecepatan rata-rata, faktor lingkungan akibat polusi yang ditimbulkan, keramahan sopir dan kondektur, keamanan dan keselamatan penumpang saat naik, berada di dalam dan turun dari Angkutan Kota, besar tarif yang berlaku, umur kendaraan, ketersediaan halte, jarak antar halte dan lokasi halte.

2. Kuadran II menunjukkan bahwa atribut yang berada pada kuadran ini dianggap sesuai oleh penumpang angkutan kota. Atribut tersebut harus tetap dipertahankan karena dapat menjadikan angkutan kota unggul menurut para penumpangnya.
Atribut yang ada pada kuadaran II antara lain: waktu pelayanan, waktu tunggu, waktu berhenti di terminal, ketepatan waktu, waktu tempuh, kebersihan tempat duduk yang disediakan, kebersihan lantai dan jendela, ketersediaan terminal dan tata letak terminal.

3. Kuadran III menunjukkan bahwa atribut yang berada pada kuadran ini bukanlah hal yang terlalu penting bagi para penumpang dan kinerjanya tidak terlalu istimewa. Peningkatan atribut yang termasuk dalam kuadran ini dapat dipertimbangkan kembali karena pengaruhnya terhadap manfaat yang dirasakan oleh penumpang sangat kecil. Atribut yang berada pada kuadran III antara lain: mudah turun naik, fasiltas pelayanan berupa TV dan audio musik yang dipasang, distribusi informasi tarif dalam angkutan kota, kriteria bangunan halte serta tempat parkir kendaraan angkutan kota.

4. Kuadaran IV menunjukkan bahwa atribut yang berada dalam kuadran ini bukanlah hal yang penting karena penumpang merasa operator terlalu berlebihan dalam melakukan pelayanan tersebut. Atribut yang berada pada kuadran IV antara lain: rute perjalanan, jarak berjalan kaki ke tempat, jumlah tempat duduk yang 
disediakan, headway, tersedianya tempat duduk setiap saat, kepadatan penumpang, kualitas tempat duduk, suhu dalam angkutan kota, sistem pembayaran tarif, jenis kendaraan, dimensi dan desain angkutan kota, jumlah armada yang beroperasi, ukuran halte, tata letak halte, kriteria bangunan terminal, Ukuran terminal serta lokasi terminal.

\subsection{Penentuan Nilai Customer Satisfaction Index}

Analisis CSI digunakan untuk mengetahui tingkat kepuasan penumpang terhadap kinerja angkutan kota di Kota Kupang secara menyeluruh dengan menggunakan kriteria nilai seperti pada Tabel 3. Berdasarkan hasil perhitungan penentuan nilai CSI maka diperoleh nilai CSI sebesar 57,21\% ( $x \leq 64 \%$, very poor). Hal ini berarti atribut-atribut pelayanan jasa yang diberikan oleh angkutan kota secara keseluruhan belum bisa dikatakan memuaskan dan atribut-atribut pelayanan tersebut perlu mendapat perhatian untuk ditingkatkan oleh operator.

\subsection{Analisis Loyalitas Penumpang}

Berdasarkan Tabel 4, skor rata-rata tingkat loyalitas penumpang adalah 3.193 (kategori 3.01 - 4.00) sehingga dapat disimpulkan responden penumpang angkutan kota dalam penelitian ini dikategorikan loyal terhadap angkutan kota yang beroperasi di kota Kupang. Hal ini menunjukkan bahwa responden dalam penelitian ini selalu menggunakan angkutan kota dalam melakukan aktivitas perjalanan.

\subsection{Permodelan Persamaan Struktural Pendekatan PLS}

\subsubsection{Pengujian Asumsi Linearitas}

Asumsi linearitas dikatakan terpenuhi jika nilai signifikansi model linear kurang dari 0.05. Sebaliknya, jika nilai signifikansi lebih dari 0.05 maka asumsi linieritas tidak terpenuhi. Pengujian ini dilakukan dengan bantuan software SPSS.

Tabel 5. Pengujian asumsi linearitas model struktural

\begin{tabular}{|c|c|c|c|c|c|c|}
\hline \multicolumn{7}{|c|}{ ANOVAC } \\
\hline & & $\begin{array}{l}\text { Sum of } \\
\text { Squares }\end{array}$ & df & Mean Square & $\mathrm{F}$ & Sig. \\
\hline \multirow[t]{3}{*}{1} & Regression & 54.543 & 1 & 54.543 & 71.874 & $.000^{2}$ \\
\hline & Residual & 97.136 & 128 & .759 & & \\
\hline & Total & 151.679 & 129 & & & \\
\hline \multirow[t]{3}{*}{2} & Regression & 126.345 & 2 & 63.172 & 316.690 & $.000^{\circ}$ \\
\hline & Residual & 25.334 & 127 & .199 & & \\
\hline & Total & 151.679 & 129 & & & \\
\hline
\end{tabular}

a. Predictors: (Constant), MEAN_PERFORMANCE

b. Predictors: (Constant), MEAN_PERFORMANCE, MEAN_IMPORTANCE

c. Dependent Variable: MEAN_LOYALITAS

Dari Tabel 5 dapat dijelaskan bahwa seluruh nilai signifikansi untuk model linear lebih kecil dari 0.05 sehingga asumsi linearitas untuk model struktural sudah terpenuhi.

Tabel 4. Tingkat loyalitas penumpang

\begin{tabular}{|c|c|c|c|c|c|c|c|}
\hline \multirow{2}{*}{ Variabel } & \multicolumn{5}{|c|}{ Skor } & \multirow{2}{*}{ Total } & \multirow{2}{*}{ Rerata } \\
\hline & 5 & 4 & 3 & 2 & 1 & & \\
\hline \multicolumn{8}{|l|}{ Behavioral } \\
\hline $\begin{array}{l}\text { Keinginan penumpang untuk menggunakan Angkutan Kota di masa yang akan } \\
\text { datang (Repurchase Behaviour). }\end{array}$ & 40 & 74 & 16 & 0 & 0 & 544 & 4.185 \\
\hline $\begin{array}{l}\text { Kecenderungan niat penumpang untuk selalu menggunakan angkutan Kota disaat } \\
\text { ingin menggunakan jasa transportasi (Repeat Purchase Intensions). }\end{array}$ & 34 & 71 & 23 & 2 & 0 & 527 & 4.054 \\
\hline \multicolumn{8}{|l|}{ Attitude } \\
\hline $\begin{array}{l}\text { Niat penumpang untuk merekomendasikan Angkutan Kota kepada orang lain } \\
\text { (word of mouth). }\end{array}$ & 23 & 67 & 39 & 1 & 0 & 502 & 3.862 \\
\hline $\begin{array}{l}\text { Niat penumpang untuk mengatakan hal-hal positif tentang Angkutan Kota kepada } \\
\text { orang lain. }\end{array}$ & 12 & 62 & 55 & 1 & 0 & 475 & 3.654 \\
\hline Niat penumpang untuk mendorong orang lain agar menggunakan Angkutan Kota. & 9 & 67 & 52 & 2 & 0 & 473 & 3.638 \\
\hline \multicolumn{8}{|l|}{ Cognitive } \\
\hline $\begin{array}{l}\text { Kerelaan penumpang untuk tetap menggunakan Angkutan Kota walaupun tarif } \\
\text { untuk menggunakan Angkutan Kota lebih mahal (Willingness to pay more). }\end{array}$ & 0 & 4 & 52 & 56 & 18 & 302 & 2.323 \\
\hline $\begin{array}{l}\text { Komitmen dari penumpang bahwa harga bukanlah masalah yang penting, dan akan } \\
\text { tetap lebih memilih Angkutan Kota (Preference). }\end{array}$ & 0 & 5 & 55 & 52 & 18 & 307 & 2.362 \\
\hline $\begin{array}{l}\text { Kecenderungan niat penumpang untuk selalu menggunakan Angkutan Kota dan } \\
\text { tidak mau menggunakan jenis kendaraan lain (choice reduction behavior). }\end{array}$ & 0 & 3 & 57 & 50 & 20 & 303 & 2.331 \\
\hline $\begin{array}{l}\text { Kecenderungan untuk menempatkan Angkutan Kota sebagai pilihan utama (first } \\
\text { choice in mind). }\end{array}$ & 0 & 2 & 56 & 55 & 17 & 303 & 2.331 \\
\hline Rata-rata Keseluruhan & & & & & & & 3.193 \\
\hline
\end{tabular}




\subsubsection{Evaluasi Measurement (Outer) Model}

Berdasarkan Gambar 2, Nilai loading factor untuk indikator $\mathrm{Y}_{1-3}$ lebih kecil dari 0.5 atau tidak signifikan. Untuk itu indikator ini harus dieliminasi dari model kemudian dilakukan kembali analisis convergent validity. Hasil analisis convergent validity yang telah dimodifikasi ditampilkan pada Gambar 3.
Keterangan :

$\mathrm{X}_{1-1} ; \mathrm{X}_{2-1}=$ Aksesibilitas

$\mathrm{X}_{1-2} ; \mathrm{X}_{2-2}=$ Kehandalan

$\mathrm{X}_{1-8}=$ Mean Performance

$\mathrm{X}_{1-3} ; \mathrm{X}_{2-3}=$ Kenyamanan

$\mathrm{X}_{1-4} ; \mathrm{X}_{2-4}=$ Keamanan dan Keselamatan

$\mathrm{X}_{2-8}=$ Mean Importance

$\mathrm{X}_{1-5} ; \mathrm{X}_{2-5}=$ Pentarifan

$\mathrm{X}_{1-6} ; \mathrm{X}_{2-6}=$ Sarana Angkutan Umum

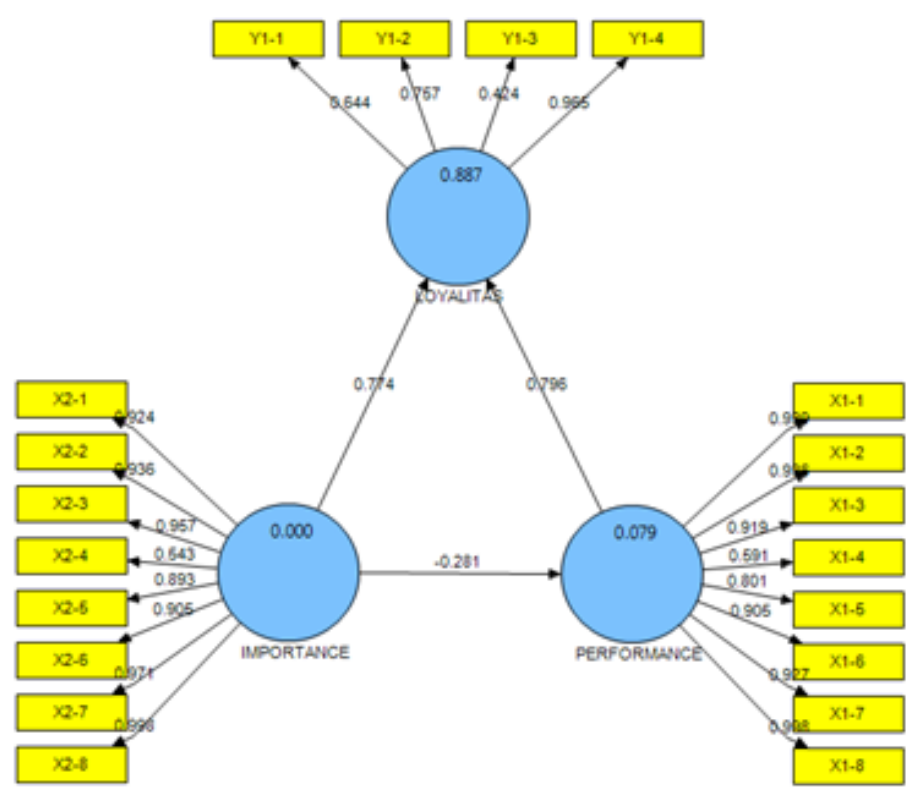

Gambar 2. Konstruksi diagram jalur hasil permodelan PLS

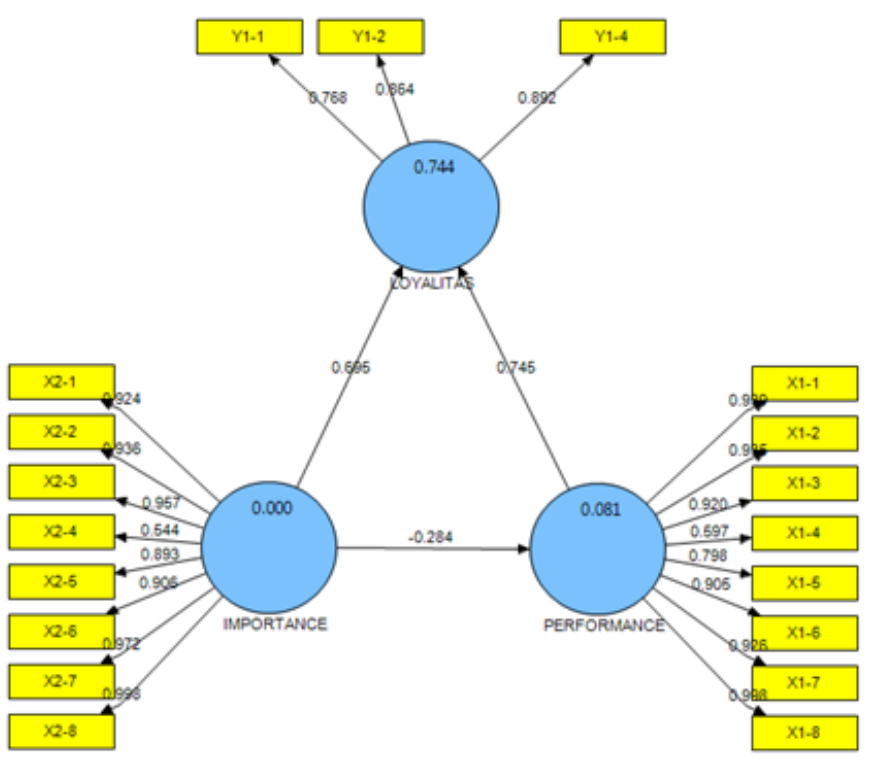

Gambar 3. Konstruksi diagram jalur hasil permodelan PLS modifikasi 
$\mathrm{X}_{1-7} ; \mathrm{X}_{2-7}=$ Prasarana Angkutan Umum

$\mathrm{Y}_{1-1}=$ Behaviour $\quad \mathrm{Y}_{1-2}=$ Attitude

$\mathrm{Y}_{1-3}=$ Cognitive $\quad \mathrm{Y}_{1-4}=$ Mean Loyalitas

Gambar 3 menunjukkan bahwa loading factor memberikan nilai di atas 0.5 berarti indikator yang dipergunakan dalam penelitian ini adalah valid atau telah memenuhi convergent validity. Selanjutnya diperoleh nilai AVE, Composite Reliability, Cronbach's Alpha dan $R$ Square yang ditampilkan dalam Tabel 6.

Tabel 6. Nilai AVE, Composite Reliability, Cronbach's Alpha dan $R$ Square

\begin{tabular}{c|c|c|c|c}
\hline \multirow{2}{*}{$\begin{array}{c}\text { Outer } \\
\text { Model }\end{array}$} & \multicolumn{2}{|c|}{ Discriminant Validity } & $\begin{array}{c}\text { Uji } \\
\text { Reliabilitas }\end{array}$ & \multirow{2}{*}{$\boldsymbol{R}^{2}$} \\
\cline { 2 - 4 } & $\boldsymbol{A V E}$ & $\begin{array}{c}\text { Composite } \\
\text { Reliability }\end{array}$ & $\begin{array}{c}\text { Cronbach } \\
\text { ' } \text { Alpha }\end{array}$ & \\
\hline \multirow{2}{*}{ Importance } & $\begin{array}{c}0.81> \\
0.5\end{array}$ & $0.97>0.7$ & $0.96>0.6$ & \\
\hline Loyalitas & $\begin{array}{c}0.71> \\
0.5\end{array}$ & $0.87>0.7$ & $0.80>0.6$ & 0.74 \\
\hline Performance & $\begin{array}{c}0.78> \\
0.5\end{array}$ & $0.96>0.7$ & $0.95>0.6$ & 0.08 \\
\hline
\end{tabular}

Tabel 6 memberikan nilai AVE diatas 0.5 untuk semua konstruk yang terdapat pada model penelitian, sehingga dapat dikatakan valid. Nilai composite reliability untuk semua konstruk diatas 0.7. Hal ini berarti semua konstruk memenuhi kriteria discriminant validity. Selain itu, uji reliabilitas juga bisa diperkuat dengan Cronbach's Alpha. Tabel 6 diatas menunjukkan bahwa nilai Cronbach's Alpha untuk semua konstruk berada di atas 0.6 sehingga dapat dikatakan reliabel.

\subsubsection{Pengujian Godness of Fit}

Pengujian Goodness of Fit model struktural pada inner model menggunakan nilai predictive-relevance $\left(\mathrm{Q}^{2}\right)$. Tabel 6 memberikan nilai $\mathrm{R}^{2}$ adalah 0.080548 untuk konstruk Performance. Artinya, Importance mampu menjelaskan varians Performance sebesar $8.0548 \%$. Nilai $\mathrm{R}^{2}$ juga terdapat pada Loyalitas yang dipengaruhi oleh Importance dan Performance yaitu sebesar 0.743705 yang berarti Importance dan Performance mampu menjelaskan varians loyalitas sebesar $74.37 \%$ dan sisanya $25.63 \%$ dijelaskan oleh variabel lain diluar yang diteliti.

Selanjutnya perolehan $\mathrm{R}^{2}$ dimasukkan ke dalam persamaan $Q$ square.

$$
\mathrm{Q}^{2}=1-\left(1-\mathrm{R}_{1}^{2}\right)\left(1-\mathrm{R}_{2}^{2}\right)
$$

Diperoleh nilai $\mathrm{Q}^{2}$ dalam penelitian ini :

$$
\begin{aligned}
& \mathrm{Q}^{2}=1-(1-0.743705)(1-0.080548) \\
& \mathrm{Q}^{2}=0.76434905
\end{aligned}
$$

Hasil perhitungan memperlihatkan nilai predictive-relevance sebesar 0.76434905 atau $76.43 \%$ dan berada diatas $61 \%$ sehingga model layak dikatakan memiliki nilai prediktif yang baik. Hal ini mengindikasikan bahwa informasi yang terkandung dalam data $76.43 \%$ dapat dijelaskan oleh model PLS tersebut. Sedangkan sisanya $23.57 \%$ dijelaskan oleh variabel lain (yang belum terkandung dalam model).

\subsubsection{Pengujian Inner Model}

Selanjutnya dilakukan pengujian hipotesis dari Inner Model dengan Bootstrapping Analysis yang ditampilkan pada Gambar 4 dan Gambar 5.

Berdasarkan analisis pengaruh atau hubungan antara Importance, Performance dan Loyalitas penumpang saat ini dengan Partial Least Square pada Gambar 4 dan Gambar 5 diperoleh :

* Importance atau harapan penumpang terhadap kinerja pelayanan angkutan kota berpengaruh signifikan terhadap Loyalitas penumpang saat ini. Hal ini ditunjukkan oleh nilai T-statistik sebesar 11.118358 (> 1.96). Dengan demikian $\mathrm{H}_{1}$ teruji kebenarannya. Sedangkan nilai original sample estimate adalah positif yaitu sebesar 0.694786. Maka arah hubungan antara importance dan loyalitas penumpang adalah positif. Hal ini dapat diinterpretasikan sebagai berikut: semakin baik kualitas pelayanan yang diberikan maka semakin tinggi tingkat loyalitas penumpang.

* Importance berpengaruh signifikan terhadap Performance atau kepuasan penumpang. Hal ini ditunjukkan oleh nilai T-statistik sebesar 3.059242 (> 1.96). Dengan demikian $\mathrm{H}_{2}$ teruji kebenarannya. Sedangkan nilai original sample estimate adalah negatif yaitu sebesar -0.283809. Nilai negatif tersebut menunjukkan bahwa importance atau harapan penumpang terhadap kinerja pelayanan angkutan kota tidak 
berpengaruh langsung terhadap loyalitas penumpang namun berpengaruh signifikan terhadap performance atau kepuasan penumpang.

* Performance atau kepuasan penumpang berpengaruh signifikan terhadap loyalitas penumpang saat ini. Hal ini ditunjukkan oleh nilai T-statistik sebesar 11.282124 (> 1.96). Dengan demikian $\mathrm{H}_{3}$ teruji kebenarannya. Sedangkan nilai original sample estimate adalah positif yaitu sebesar 0.744782. Maka arah hubungan antara importance dan loyalitas penumpang adalah positif.

Berdasarkan hasil analisis data yang telah dilakukan maka dapat dilihat bahwa kualitas pelayanan berpengaruh signifikan positif terhadap loyalitas. Hal ini didukung oleh

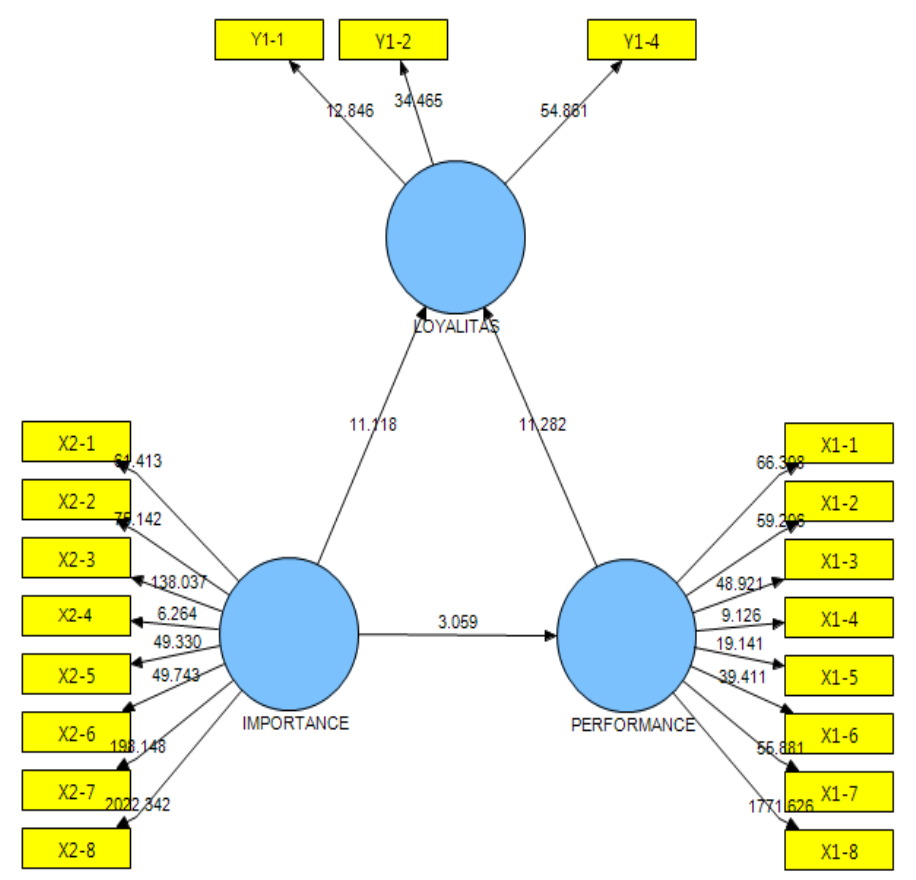

Gambar 4. Output bootstrapping output PLS

\begin{tabular}{|c|c|c|c|c|}
\hline & $\begin{array}{c}\text { Original Sample } \\
(0)\end{array}$ & Sample Mean (M) & $\begin{array}{c}\text { Standard } \\
\text { Deviation } \\
\text { (STDEV) }\end{array}$ & $\begin{array}{c}\text { Standard Error } \\
\text { (STERR) }\end{array}$ \\
\hline $\begin{array}{c}\text { IMPORTANCE -> } \\
\text { LOYALITAS }\end{array}$ & 0.694786 & 0.695923 & 0.062490 & 0.062490 \\
\hline $\begin{array}{c}\text { IMPORTANCE -> } \\
\text { PERFORMANCE }\end{array}$ & -0.283809 & -0.281387 & 0.092771 & 0.092771 \\
\hline $\begin{array}{c}\text { PERFORMANCE - } \\
\text { LOYALITAS }\end{array}$ & 0.744782 & 0.745355 & 0.066014 & 0.066014 \\
\hline
\end{tabular}

\begin{tabular}{|c|c|}
\hline & $\begin{array}{c}\text { T Statistics } \\
(\mid \mathrm{O} / \text { STERR } \mid)\end{array}$ \\
\hline $\begin{array}{c}\text { IMPORTANCE }-> \\
\text { LOYALITAS }\end{array}$ & 11.118358 \\
\hline $\begin{array}{c}\text { IMPORTANCE }-> \\
\text { PERFORMANCE }\end{array}$ & 3.059242 \\
\hline $\begin{array}{c}\text { PERFORMANCE }-> \\
\text { LOYALITAS }\end{array}$ & 11.282124 \\
\hline
\end{tabular}

Gambar 5. Uji hipotesis inner model output PLS 
hasil penelitian yang dilakukan oleh Uma \& Chandramowleeswaran [12] yang menyatakan bahwa perubahan pelayanan suatu perusahaan/penyedia jasa akan memberikan dampak yang positif terhadap loyalitas.

Selain itu, ada pula penelitian yang menunjukkan bahwa kepuasan pelanggan berpengaruh secara positif terhadap loyalitas pelanggan yakni penelitian yang dilakukan oleh Hussein \& Hapsari [4].

Secara umum, penelitian ini menemukan bahwa terdapat hubungan antara variabel-variabel seperti kualitas layanan (importance) dan kepuasan penumpang (performance) dengan loyalitas. Hasil penelitian ini relevan dengan penelitian yang dilakukan oleh Esmaeili, et. Al [3].

\section{KESIMPULAN}

1. Pengaruh kualitas pelayanan angkutan kota terhadap kepuasan dan loyalitas penumpang di kota Kupang yaitu :

a. Penumpang angkutan kota dalam penelitian ini dikategorikan loyal terhadap angkutan kota yang beroperasi di kota Kupang.

b. Nilai CSI diperoleh 57.21\% ( $x \leq 64 \%$, very poor). Hal ini berarti atribut-atribut pelayanan jasa yang diberikan oleh angkutan kota secara keseluruhan belum bisa dikatakan memuaskan dan atribut-atribut pelayanan tersebut perlu mendapat perhatian untuk ditingkatkan oleh operator.

c. Variabel pelayanan yang menjadi prioritas utama perbaikan kinerja angkutan kota menurut penumpang adalah perpindahan angkutan kota, panjang trayek yang dilalui angkutan kota, kecepatan rata-rata angkutan kota, faktor lingkungan akibat polusi yang ditimbulkan (asap kendaraan dan kebisingan), keramahan sopir dan kondektur angkutan kota, keamanan dan keselamatan penumpang, besar tarif yang berlaku untuk angkutan kota, umur kendaraan angkutan kota, ketersediaan halte, jarak antar halte dan lokasi halte. d. Pengaruh atau hubungan antara importance, performance dan loyalitas penumpang di kota Kupang adalah :

$$
\text { * Importance atau harapan }
$$
penumpang terhadap kinerja pelayanan angkutan kota di kota Kupang berpengaruh signifikan terhadap Loyalitas penumpang saat ini.

$\begin{array}{lcr}\text { * Importance atau } & \text { harapan } \\ \text { penumpang terhadap } & \text { kinerja }\end{array}$ pelayanan angkutan kota di kota Kupang berpengaruh signifikan terhadap Performance atau kepuasan penumpang.

* Performance atau kepuasan penumpang angkutan kota di kota Kupang berpengaruh signifikan terhadap Loyalitas penumpang saat ini.

2. Upaya peningkatan kinerja angkutan kota di kota Kupang terhadap kepuasan penumpang angkutan kota untuk meningkatkatkan loyalitasnya yaitu dengan melakukan perbaikan terhadap item kinerja pelayanan yang menjadi prioritas utama pelayanan angkutan kota yang telah disebutkan sebelumnya.

\section{DAFTAR PUSTAKA}

[1] Bahar, Taslim. (2013). Kualitas Pelayanan Dan Loyalitas Penggunaan Ojek Sepedamotor Sebagai Angkutan Umum Penumpang Perkotaan. Majalah Ilmiah "MEKTEK". Tahun XV NO. 2.

[2] De Ona, Juan dan De Ona, Racio. 2014. Quality Of Service In Public Transport Based On Customer Satisfaction Surveys: A Review And Assessment of Methodological Approaches. Transportation Science, DOI: 10.1287/trsc.2014.0544.

[3] Esmaeili, Manesh dan Golshan. 2013. Service Quality, Customer Satisfaction and Customer Loyalty in RAJA Rail Transportation Company. International Research Journal of Applied and Basic Sciences, Vol. 5 (3).

[4] Hussein dan Hapsari. 2014. How Quality, Value And Satisfaction Create Passenger Loyalty: An Empirical Study On Indonesia Bus Rapid Transit Passenger. The International Journal of Accounting and Business Society, Vol. 22, No. 2.

[5] Kumari, Neetu dan Patyal, Sandeep. 2017. Customer To Consumer: Attitudinal And 
Behavioural Loyalty. International Journal of Management Studies, Vol-IV, Issue-1.

[6] Lesmana, Hendra. 2017. Analysis of Satisfaction and Loyalty of the Quality of Service Users Industrial Area Mm2100 Bekasi District West Java. Journal of Business and Management (IOSR-JBM), Volume 19, Issue 8.

[7] Murambi, D. Nyongesa. 2014. Service Quality and Customer Satisfaction in Public Transport Sector of Kenya: A Survey of Shuttle Travelers in Kitale Terminus. International Journal of Academic Research in Business and Social Sciences, Vol.4, No.9.

[8] Purnawan dan Sanjaya. 2017. Important Performance Analysis As A Strategic Planning Technique In Bus Rapid Transit Development Program. International Journal of Civil Engineering and Technology (IJCIET), Volume 8, Issue 10.

[9] Putra, Adris., et. al. 2014. The Satisfaction Analysis for the Performance of Public Transport Urban Areas. International Refereed Journal of Engineering and Science (IRJES) Volume 3, Issue 8.
[10] Supriatin. 20 Oktober 2015. Uniknya Angkutan Umum Di Kupang, Disebut Bemo Dan Penuh Poster. Merdeka.com.

[11] Syukri, Siti H. A. 2014. Penerapan Customer Satisfaction Index (Csi) Dan Analisis Gap Pada Kualitas Pelayanan Trans Jogja. JITI, 13(2), Des 2014, pp.(103-111).

[12] Uma dan Chandramowleeswaran. 2015. A Study On Service Customization Impact Towards Customer Satisfaction, Loyalty And Trust. International Journal of Management (IJM), Volume 6, Issue 10.

[13] Van Lierop, et. al. 2018. What influences satisfaction and loyalty in public transit? A critical review of the literature. Transport Reviews, 8(1), 52-72.

[14] Vernekar, et. al. 2014. Prediction Of Soil Urea Content Using Rf Spectroscopy And Partial Least Square Regression. International Journal of Electronics and Communication Engineering and Technology (IJECET), Volume 5, Issue 11. 